\title{
PERFIL EXPORTADOR DE MULTINACIONAIS DO SETOR AUTOMOBILÍSTICO NO BRASIL
}

\author{
Larissa da Cunha Modolo*, Bruno Brandão Fischer.
}

\section{Resumo}

A pesquisa tem como objetivo examinar se há relação entre o investimento direto realizado por multinacionais estrangeiras no setor automobilístico brasileiro e o desempenho exportador do setor para a América Latina.

\section{Palavras-chave:}

Investimento Estrangeiro Direto, Indústria Automobilística, América Latina.

\section{Introdução}

O mercado brasileiro tem se mostrado atrativo para os investidores internacionais, em 2017 atraiu cerca de 40\% dos fluxos totais de investimento estrangeiro direto (IED) destinado à América Latina (UNCTAD, 2018¹). O setor automobilístico possui importante participação na economia brasileira, visto que foi responsável, em 2015, por $22 \%$ do PIB da indústria de transformação e $4 \%$ do PIB total do país (ANFAVEA, 2018²).

$O$ presente trabalho tem como finalidade averiguar se os investimentos diretos realizados por empresas estrangeiras no setor automobilístico brasileiro tiveram como propósito atingir não apenas o mercado interno brasileiro, mas outros novos mercados localizados geograficamente próximos, àqueles pertencentes a América Latina.

\section{Resultados e Discussão}

Historicamente o Brasil tem um papel de destaque na atração de IED na América Latina. Há diversos fatores que explicam esse cenário: o Brasil possui a maior economia da região e uma das maiores economias do mundo; detém um grande mercado consumidor; apresenta uma economia diversificada; há abundantes fontes de matérias-primas; sua localização geográfica torna fácil 0 acesso a outros mercados latinoamericanos; entre outros (APEX-BRASIL, 2018³).

Gráfico 1 - Investimento no setor de autoveículos brasileiro. Milhões de US\$.

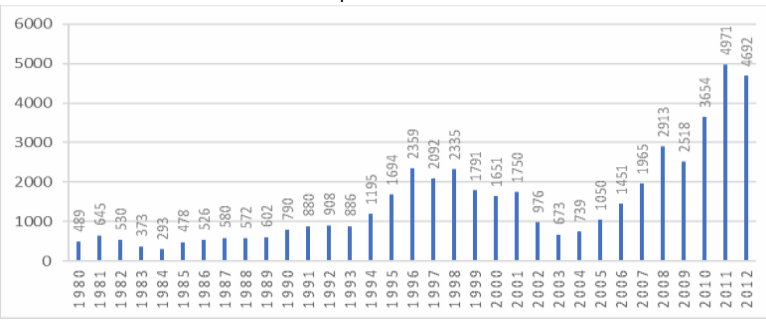

Fonte: Anfavea - Anuário da Indústria Automobilística 20144. Elaboração própria.

Pela característica do setor automobilístico brasileiro, que é composto por multinacionais estrangeiras, o investimento realizado por elas, foi no trabalho considerado como IED.

Os investimentos no setor tiveram crescimento na década de 90, no entanto, nos anos 2000 esse processo se intensificou e resultou em um setor intenso em tecnologia, com maior produtividade e mais competitivo. Houve no período a entrada de novas empresas no mercado brasileiro, provenientes da Ásia. Essas mudanças propiciaram a transformação do Brasil em centro consumidor e em plataforma regional de produção e distribuição de automóveis para a América do Sul
(COSTA, HENKIN 20165). O país alcançou a posição de 9 maior produtor mundial de automóveis e $08^{\circ}$ maior mercado interno, no ano 2017 (ANFAVEA, 2018²).

Gráfico 2 - Exportação de veículos para América Latina. Valor FOB (US\$).

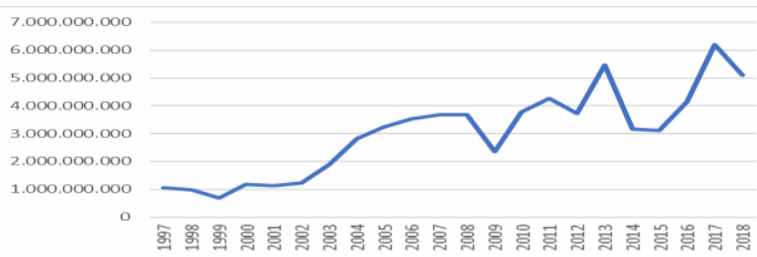

Fonte: ComexStat, 20186. Elaboração própria.

Gráfico 3- Correlação entre exportação para América Latina e Investimento no setor automobilístico.

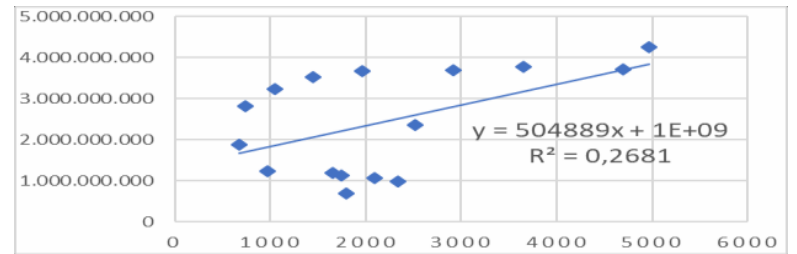

Fonte: Anfavea, $2014^{4}$ e ComexStat, 20186. Elaboração própria.

Ao analisar os investimentos realizados no setor automotivo brasileiro, e as exportações para a América Latina, foi possível realizar uma análise de correlação bivariada entre essas duas variáveis no período 1997 2018. O coeficiente de correlação encontrado foi de r: 0,52 . O resultado encontrado mostra que existe uma correlação positiva entre as duas variáveis.

\section{Conclusões}

Através da análise de correlação foi observado que existe entre as variáveis uma correlação linear, de característica moderada. Assim, outros fatores que não apenas a exportação para a América Latina pode explicar os fluxos de IED para o setor automobilístico no Brasil feito pelas empresas estrangeiras.

\section{Agradecimentos}

Ao professor Bruno Brandão Fischer e ao PIBIC/CNPq.

${ }^{1}$ UNCTAD (2018). World Investment Report 2018. Investment and New Industrial Policies. United Nations, New York and Geneva. ${ }^{2}$ ANFAVEA. Anuário da Indústria Automobilística Brasileira 2018. São Paulo: Anfavea, 2018. ${ }^{3}$ APEX-BRASIL. Investment Guide to Brasil 2018. Brasília: ApexBrasil, 2018. ${ }^{4}$ ANFAVEA. Anuário da Indústria Automobilística Brasileira 2014. São Paulo: Anfavea, 2014. ${ }^{5}$ COSTA, Rodrigo Morem da; HENKIN, Hélio. Estratégias competitivas e desempenho da indústria automobilística no Brasil. Economia e Sociedade, [s.1.], v. 25, n. 2, p.457-487, ago. 2016 ${ }^{6}$ ComexStat. Exportação e Importação Geral. 2018. Disponível em: $<$ http://comexstat.mdic.gov.br/pt/geral>. jj. 